\title{
The Bank Deposit and Wholesale Guarantees of 12 October 2008: An Appraisal
}

\author{
W. P. Hogan ${ }^{1}$
}

\begin{abstract}
The Australian Government's guarantee of funds lodged with deposit-taking entities in Australia, and of security issues by Australian banks, has fostered support for smaller and less well-placed financial entities compared to the four major Australian banks. In applying in these settings there is a prospect of moral hazard in the benefited entities. With respect to the issue guarantee, there are grounds for expecting the prudential authorities to take steps to ensure that the funding support is not dissipated in fostering more risky asset portfolios.
\end{abstract}

\section{Introduction}

On 12 October 2008, the Australian Government announced a set of arrangements for the protection of depositors in Australian deposit-taking institutions (ADIs) and a guarantee of the wholesale funding of these institutions. ${ }^{2}$ Thus there are now two distinct guarantees - a deposit guarantee and an issue guarantee that embrace the great bulk of liabilities of any Australian bank.

The aim of these measures was to promote stability in the Australian financial system by supporting confidence in the participating financial intermediaries, and to ensure continued access to funding at a time of much disturbance in international financial markets.

The decision to offer both deposit and wholesale funding guarantees on the scale announced on 12 October was unprecedented. Such a possibility had never been contemplated in any prior discussions. Repercussions from these measures have brought additional commitments to compensate financial entities other than deposit-taking institutions for their loss of a 'level playing field'. What, then, are we to make of this most substantial commitment?

\footnotetext{
1 The School of Finance and Economics, the University of Technology, Sydney, Warren.Hogan@uts.edu.au. I am grateful to S. M. Auld, W. Evans and W. P. B. Hogan, as well as referees, for comments and suggestions towards the development of this paper.

2 These measures apply to all entities incorporated in Australia; equally to foreign-owned as to Australian-owned ADIs. Branches are limited in their coverage by these guarantees.
} 


\section{The Scheme}

This deposit guarantee applies to deposits over $\$ 1$ million for each customer in any one ADI, and for which a fee to secure the guarantee is charged. Participation in the scheme is voluntary. For deposits of $\$ 1$ million or less, there was a separate guarantee under the Financial Claims Scheme; this guarantee is free.

The wholesale funding guarantee is designed to ensure Australian entities seeking to access international capital markets are not at a disadvantage to other internationally-operating competitors. In effect the guarantee offered by the Australian Government amounts to accepting the counterparty risk to which the foreign lender would otherwise be exposed when contributing to any bond or commercial paper issues by an Australian ADI. The effect is the same for lenders to these entities in the domestic capital market.

The wholesale funding provisions distinguish between short-term and longer-term liabilities. The former are defined as bank bills, certificates of deposit, transferable deposits, debentures as defined for tax purposes, and commercial paper with maturities up to 15 months. The longer-term wholesale liabilities are for maturities between 15n months and 60 months. They comprise bonds, notes and debentures, again as defined for tax purposes. There is a strict provision which eliminates what are referred to as 'complex instruments', which one might interpret reasonably as any item exhibiting derivative or similar characteristics. In effect, the guarantees are directed to supporting plain-vanilla instruments, a not-unreasonable condition in the current murky world.

The fee structures for the guarantees were based upon the assessments of the quality of the entities as determined by ratings agencies. Where there were discrepancies between ratings agencies, with no predominant classification, then the lowest rating would apply. ${ }^{3}$ The fee payable is set as basis points per annum, so that for entities rated between AAA and AA- the fee is 70; for entities between $\mathrm{A}+$ and $\mathrm{A}-$ it is 100; and for $\mathrm{BBB}+$ and below, including unrated entities, the fee is 150. ${ }^{4}$ The four major Australian banks are rated AA. However, the administrator of the guarantee scheme reserves the possibility of charging fees different from these three listed items. The rating applicable on the day of issuance of the securities is the basis for determining the fees.

There is an exception to the general rule about fees to be charged on deposit liabilities of Australian residents with Australian branches of foreign banks. Those banks, not being incorporated in Australia, do not qualify for the general deposit guarantee without fee for deposits up to and including \$1 million. Moreover, the wholesale funding guarantee applies only to short-term maturities

\footnotetext{
${ }^{3}$ The three ratings agencies referred to in the documents are Standard \& Poor's and Fitch, both reflecting the categories listed in the fee schedule, while Moody's scale would be matched for equivalence.

${ }^{4}$ This means an increase in the effective interest-rate cost to the issuer of $0.7,1.0$ and 1.5 per cent respectively for the three categories.
} 
up to 15 months and there is no provision for guarantees on longer-term issuance. Additional strict conditions apply which contain the extent of the guarantee of residents' deposits with these branches. Guaranteed liabilities cannot exceed 110 per cent of the average daily value of deposits and short-term wholesale liabilities held by Australian residents in the 30 days up to 24 October. In effect, these branches cannot use the guarantee scheme to boost funding from Australian sources.

The measures apply for three years, though the maturity of guaranteed issues may be up to five years; namely, 2014.

\section{The Background}

Recent Australian discussions about the provision of guarantee schemes for deposits in financial institutions have their origin in the investigation into the collapse of Australia's then-largest general insurance company, HIH. The Royal Commission into this failure reported in April 2003. Amongst its many findings was a recommendation to the effect that '... the Commonwealth Government introduce a systematic scheme to support policy holders of insurance companies in the event of failure of any such company'.

The response of the Commonwealth Government on 12 September 2003 was to establish a technical study into the suitability of explicit guarantees of some retail financial products, including implications for financial stability and the monitoring of financial institutions. ${ }^{5}$ This official response reflected a judgement denying scope for putting in place an explicit guarantee for one segment of the financial-services sector without regard for implications for other segments, whether it be for all deposit-taking institutions, general insurance companies, life insurances and managed funds of all descriptions including superannuation funds.

The study had as its purpose the presentation of 'a balanced framework in which the general arguments in favour of, and against, limit explicit guarantees in Australia's financial system can be considered' (Davis 2004: 60). What was provided was a comprehensive study of all issues bearing upon the applicability of such guarantees in the broad context of arrangements for the conduct, monitoring and supervision of the Australian financial system.

Apart from reviewing the recent history bearing upon issues related to guarantees, the study offered a comprehensive review of regulatory philosophy, an economic rationale for these guarantees, consequences of institutional failure, guarantee coverage, guarantee costs, funding and pricing of guarantees, and governance, accountability and regulatory impacts. Essentially the study offered

${ }^{5}$ The study was undertaken by Kevin Davis, University of Melbourne, supported by a secretariat drawn from the Commonwealth Treasury, the Reserve Bank of Australia and the Australian Prudential Regulation Authority (APRA). Public submissions were received. 
a systematic framework for the analysis of any proposals for the offering of explicit guarantees. With this work there can be no ignoring the complexity which might arise for some limited guarantees on prudential, insolvency and consumer-protection provisions bearing upon financial services entities.

There were no specific recommendations about limited explicit guarantees.

\section{Developments}

Further work on issues related to guarantees to depositors and policyholders has continued under the aegis of the Council of Financial Regulators, a non-statutory body comprising the heads of the RBA, The Treasury, APRA and the Australian Securities and Investments Commission (ASIC). ${ }^{6}$ The context in which the Council has advanced its understanding of the issues explored initially in the Study of Official Guarantee Schemes appears to be related to crisis-management arrangements.

There was recognition by the Council of the public perception of a government guarantee for the repayment of deposits, in full or in part, from a failed financial institution. In public surveys undertaken on behalf of the Council this perception was found to be most salient for banks but existed also to a substantial extent for other entities such as general insurers. The initial advice given to the Treasurer by the Council was for the establishment of a Financial Claims Compensation Scheme which would give depositors and policyholders timely access to funds in the event of closure of an authorised deposit-taking institution or general insurer (RBA 2006a). The maximum payment would be capped at $\$ 50,000$. The response was to have the Council consult on the proposal with the finance sector.

The consultations were extensive, involving the various associations linked to deposit-taking institutions and insurance activities. There was opposition to the original proposal, reflecting a variety of arguments invoking moral hazard arising from the diminution of market discipline. The insurance representatives had other concerns involving broader issues of a regulatory nature outside the reach of the Council (RBA 2006b). Following these discussions, the Council reported to the Treasurer with revisions to the original scheme, including reducing the cap to $\$ 20,000$.

In June 2008, the then Commonwealth Government announced a decision to implement a financial-claims scheme along the lines of the proposals from the Council. The upper limit would be $\$ 20,000$. APRA would administer the scheme and have first claim over the assets of the failed institution to meet the cost of

\footnotetext{
${ }^{6}$ While this council once provided reports on its activities, these were abandoned in 2003, with subsequent reporting on activities of the Council being offered in the reports coming from the four constituent members. The main reference for the purposes of this contribution is the Financial Stability Review issued at six-monthly intervals by the Reserve Bank of Australia.
} 
the claims funded. Only if APRA could not recover the total costs associated with the funding of the claims under the scheme would there be a levy on the surviving entities in the activity associated with the failed institution (RBA 2008).

\section{The Deposit Guarantees: Some Consequences}

This appraisal, over the past five years or thereabouts, of possibilities for deposit guarantees reveals very little relationship between what was announced early in October 2008 and the assessments made on guarantees and their costs made prior to that announcement. The Council of Financial Regulators had developed a proposal offering access to funds held in failed institutions but limited to about $\$ 20,000$ per account or policy, be they in a deposit-taking entity or an insurance company.

The guarantee announcement of October 2008 placed all the deposit-taking entities - banks, building societies and credit unions - in a privileged cocoon within the financial services sector. In effect, the measures were designed to protect the great bulk of liabilities of these entities thus ensuring their priority in funding their asset portfolios. This segmentation of the financial-services sector brought repercussions for all other participants, these being managed funds of many varieties including superannuation funds, and property trusts. This segmentation was the very feature the Council of Financial Regulators was trying to avoid with its proposal to provide liquidity to those with funds locked up in failed institutions, whether deposit-taking or insurance.

The Australian Government was well aware at the time of the announcement how this segmentation might bring troubles to entities outside the cocoon. Thus the Australian Office of Financial Management (AOFM) was instructed to buy $\$ 4$ billion of residential mortgage-backed securities to inject some liquidity into portfolios of entities holding such claims. This action was seen as a benefit to the mortgage market '.. by levelling the playing field for non-ADI institutions and ensuring that this sector of the lending market has access to funding' (Rudd 2008).

This action foreshadowed likely further efforts to 'compensate' activities such as property trusts for their loss of this 'level playing field' for access to funds. The Australian Treasurer reflected concerns for the non-prudentially regulated investment sector and an interest in ways the vitality of these activities might be fostered (Swan 2008).

\section{The Issuance Guarantees: Some Data on the Consequences}

Within the scheme, the fee structure does not impress as reflecting the full range of variations associated with the categories determined by ratings agencies. From top to bottom the range is only 80 basis points. This is much less than the spreads 
often witnessed in international capital markets between the highly-rated and the lesser-rated ones when funding is sought: hence the need for examination of available evidence on the pricing of issues prior to and then subsequent to the provision of the guarantees.

The evidence presented in Table 1 is based upon the costs of raising funds in international capital markets. Effectively, this means the London market, where the pricing is determined by the London Inter Bank Offered Rate (LIBOR). LIBOR covers rates in different currencies and for different maturities. That pricing permeates pricing in other money and financial markets around the world.

The spread shown in Table 1 is the margin based upon the overnight cash rate, the three-month bank bill rate and the maturity structures related to those two series. Australian interbank lending is by means of the Bank Bill swap rate (BBSW), most commonly with a maturity of three months. An interest-rate swap comes about when one party is willing to pay a fixed rate to the other party the counterparty in the transaction - while agreeing to receive the average cash rate over the life of the swap, usually three months.

The spread is the difference between the interest rate a party is willing to pay and the bank bill rate applicable to the maturity of the swap. This is approximately equivalent to a risk-free rate. Note the important feature here: the spread measures the difference between borrowings with a specified maturity and the cash rate overnight. The spread is independent of the level of the cash rate. Hence, the spread tells all about risk perceptions about the issuer entity, thus reflecting features guiding pricing in these money markets.

The spreads shown in Table 1 reflect the differences in value between bank securities, being three-year securities, notes and bonds, and the swap rate at the time of issuance. Thus the estimates shown in Table 1 are based upon three-year fixed rates.

Table 1: Issuance Costs and the Spread (basis points)

\begin{tabular}{|l|l|l|l|}
\hline & AA & A + \&A & BBB + \\
\hline (a) March 07 & $+15 / 20$ & $+20 / 25$ & $+30 / 35$ \\
\hline (b) March 08 & $+90 / 100$ & $+125 / 150$ & $+180 / 250$ \\
\hline (c) March 09 & $+50 / 60$ & $+75 / 85$ & $+85 / 95$ \\
\hline (d) Cost to ADI of Government Guarantee & 70 & 100 & 150 \\
\hline $\begin{array}{l}\text { (e) Effective margin } \\
=\text { (c) }+ \text { (d) }\end{array}$ & 125 & 180 & 240 \\
\hline
\end{tabular}

Source: ANZ Bank: Economics \& Markets Research

The three periods chosen reflect market conditions in and around March 2007, this being a time prior to the turbulence which beset money markets later that year. March 2008 marks the time of great instability and turmoil following the collapse of important financial entities in the United States with grave 
consequences for pricing risks. March 2009 reflects a time of much greater involvement of governments and central banks in market activities and many months after the decision of the Australian Government to offer guarantees to Australian-based issuers in international capital markets.

The range of the spreads increased substantially in the March 08 period when markets were strained severely by liquidity and other problems, mainly about risks. This was most severe for the lowest-rated securities shown in the BBB+ column in Table 1.

The impact of the guarantee is depicted in the final row in the table. This measure is taken from the mid point of the range for the three rated categories in the third row of the table and added to the cost of the guarantee associated with each of those three categories revealed in the fourth row.

The effects of the guarantee may best be glimpsed from a comparison of the differences in the spreads between the three categories, especially in the tumultuous March 2009 period, with the effective margin linked to the implementation of the guarantees. At that time, the spread of the lowest-rated category $(\mathrm{BBB}+)$ was twice or more greater than the spread for the AA category (180/250 vs 90/100). The effect of the guarantee, and the costs charged for it, is shown by the compression of that margin between the AA and the $\mathrm{BBB}+$ to less than twice the difference between the spreads for the two series (240 vs 125). The same compression applied to the middle series of the three rated categories $(\mathrm{A}+\& \mathrm{~A})$.

This information on spreads across different rated categories of issuers is revealing of the effects of market intervention and the pricing of guarantees. That pricing has favoured the lesser-rated entities issuing in international capital markets. In effect, the cost of the guarantee has not reflected the relative risks associated with the issuers.

The effect of the wholesale funding guarantee offered by the Australian Government with its AAA rating, then, is to compress the variation in the cost of funds between differently-rated banks. The effect amounts to a form of subsidisation of the lesser entities by the highly-rated ones - in this setting, the four major Australian banks.

Banks have seized the opportunities afforded by the government guarantee to extend the maturities of their wholesale funding to bring stability into their funding arrangements and not be prone to market instability when relying on shorter-term funding from capital markets.

Nine banks have used guaranteed funding, drawing two-thirds of the sums involved from foreign sources, apparently predominantly through placements in the United States and, more recently, offerings in the Japanese samurai market. 
The great bulk of the short-term wholesale funding has been in the domestic market.

\section{The General Consequences: Some Evidence}

The guarantees have been used comprehensively, according to the most recent information as shown in Table 2. The schemes became effective on 28 November 2008 so, at the time of writing, there has been just four months' experience. There has been a rapid adaptation of funding arrangements, with a shift from short-term wholesale funding to longer-term wholesale funding within in this brief period. The December series includes the last three days of November at the start of the scheme. The March data applies up to 24 March 2009.

\section{Table 2: Guaranteed Sums (\$bn) (daily average value)}

\begin{tabular}{|l|l|l|l|l|}
\hline & Dec08 & Jan09 & Feb09 & Mar09* \\
\hline Deposits** & 18.9 & 19.0 & 19.3 & - \\
\hline Short-term WF** & 15.4 & 19.4 & 22.4 & 18.9 \\
\hline Long-term WF** & 8.6 & 35.9 & 60.4 & 81.2 \\
\hline Total & 42.1 & 74.5 & 102.2 & - \\
\hline $\begin{array}{l}\text { Memorandum item } \\
\text { Fees }(\$ \mathrm{~m})\end{array}$ & 32.7 & 51.3 & 63.2 & - \\
\hline
\end{tabular}

*data up to 24 March 2009

** daily average values

Source: RBA 2009: 28

The final row records the fees paid during the first three months.

This dominance of the longer maturities - three to five years - reflects the advantages conferred by the guarantee, allowing stability in funding asset portfolios and curtailing exposure to short-term variability in market conditions. There is no doubt about this positive impact for bank portfolio management because the banks issued a mere $\$ 3.5$ billion in term debt in the three months September to November 2008. ${ }^{7}$ This shift has compensated also for the very sharp falls in issues of asset-backed securities and residential mortgage-backed securities between 2005-07 and now.

The effects of the guarantees have been pervasive, being felt in the deposit market as well as the wholesale funding aspects mentioned above. Major banks gained share during the economic and financial turbulence prior to the announcement of the guarantees. Smaller institutions regained some of their lost share after the announcement of the deposit guarantee. ${ }^{8}$

The fees paid, as depicted in the memorandum item in Table 1, reflect the very stable values for insured deposits over \$1 million in value; the deposit holders opt in for the guarantee rather than banks having blanket coverage for

7 This was the period of greatest market turmoil associated with the failure of Lehman Brothers and distress amongst any number of banks in the United States and Europe, especially the United Kingdom.

${ }^{8}$ Substantial commentaries on market conditions and influences are offered in the moist recent Financial Stability review (RBA 2009: 26-32). 
all these large deposits. The very rapid growth in the values of fees paid reflects the increases in the values of the wholesale funding issuances guaranteed by the Australian Government.

There has been a proliferation of various funding-support devices subsequent to the announcement of the guarantees. A specialised support vehicle was devised to provide funds for financing purchases of motor vehicles with the exit of GE Finance from such lending in Australia as well as the diminution of activities in the same sphere from General Motors Acceptance Corporation. This combination of government and bank funding is likely to be repeated in other specialised excursions into sectoral funding.

More revealing is the role of the Australian Office of Financial Management (AOFM). This government funding office has been committed to support the property market through the funding of residential-mortgage-backed securities, as indicated by the Australian Treasurer (Swan 2008). The AOFM acts as the 'cornerstone investor' in issues of residential-mortgage-backed securities, most of which are on behalf of property trusts and the like, though the Bank of Queensland is the issuer of a proposal in the second round of offerings. ${ }^{9}$

\section{Appraisal}

The strength of the four major Australian banks on the international scene is acknowledged and proclaimed. This feature was expressed firmly by the Deputy Prime Minister in her speech to the World Economic Forum when she stated: 'Australia has strong financial institutions. Of the 11 banks around the world that are rated AA and above, four of them are Australian. Australia has a AAA foreign currency rating' (Gillard 2009). This statement raises questions as to why the major intervention incurred by the guarantees was deemed necessary. With few banks as strong as the four Australian majors, the claim about their need for support in raising international funds is not convincing, despite the harsh experiences during October and November 2008. Even less reason would there be to impose the market segmentation brought about by the domestic guarantees on deposits. Deposits were shifting to the four majors compared with lesser deposit-taking entities (RBA 2009: 29).

The decision on the guarantees supporting funding in international capital markets reflected the gross turbulence following the failure of Lehman Brothers in September 2008. Counterparty and settlement risks were at the heart of the gross dislocation. Hence, the decision to provide guarantees was aimed at settling international capital markets with respect to completion of transactions, though the capacity to fund remained a test of market liquidity. Insofar as the borrowings of the major banks are the means of funding shortfalls in the balance of payments

\footnotetext{
${ }^{9}$ This funding may be seen as a measure of liquidity support for a BBB+ rated bank not willing to explore a market placement of its paper even with the guarantee from the Australian Government.
} 
on current account, there is a national interest to be served in bringing a strong measure of stability to these funding mechanisms.

Some further sense may be made of this drastic policy intervention if one allows the possibility that the Council of Financial Regulators had worries about the less well-placed financial institutions other than the four majors, and advised government accordingly. For deposit guarantees the evidence points to the superior position held by the four majors compared to other deposit-taking entities, including the building societies and credit unions. With the funding guarantees that nine banks took advantage of, the offering may be interpreted as some support for thinking the lesser-rated banks gained access to funds which would otherwise have been denied them. All the banks seized the distinct advantage in turbulent times of locking in funding for some years. Yet the policy initiative was an obvious gain for the less well-placed in the banking fraternity compared to the four majors, all of whom have been well to the fore with issuance.

Domestically, the placement of funds with the deposit-taking entities, whether as formal deposits or short-term wholesale funding, is relatively attractive when compared to other outlets because of the guarantee. We should bear in mind the impact of these measures on the relative standing of state governments in capital markets, where they stood less-well ranked than building societies and credit unions nourished by Australian Government credibility! Holders of state government securities were immediately handicapped because the values of these securities declined relative to those securities issued by guaranteed entities. This impact led to the later commitment to support from the Australian Government to ensure new issues being taken up by financial intermediaries and managed funds. The purpose of this step was to support the maintenance of capital spending by state governments.

But the priority achieved comes at the cost of the guarantee thus adding to the cost of funds. Hence, the scope for adjusting interest rates to match official cash-rate adjustments may be restricted, quite apart from any influences arising in international capital markets on the pricing of longer term wholesale funds.

\section{Some Macroeconomic Questions}

Macroeconomic implications arise with the proliferation of measures following on the deposit and funding guarantees. Some flow from the extension of support to the property market, with further prospect for domestic funding of property vehicles to substitute for foreign borrowings. Should foreign lenders face liquidity strains in their home markets, the likelihood of negotiating effective re-financing with them when they are aware of alternative sources to meet borrowers' needs looks to be remote. Capital account impacts cannot be ignored. 
These macroeconomic prospects are challenged further should there be a rapid increase in Australian Government issues of bonds to fund total requirements involving budget commitments and those of entities created to meet extra-budgetary needs (with the AOFM being an example). This expansion is likely to stimulate some lift in the term structure of interest rates as well as their overall level. In this setting, the offering of Australian Government guarantees of debt issuances by banks and other deposit-taking institutions adds to the supply of this official paper, especially on foreign markets. This expansion will be further extended should the Australian Government establish additional special-funding vehicles to support efforts to compensate with level playing fields to offset the effects of market segmentation.

Consequences may flow from this setting for relative value of the Australian dollar. Some funding is attracted to AUD-denominated borrowings because of the relatively high yield. But foreigners' willingness to participate in these issues may be hampered by exchange-rate volatility. Hence, the maintenance of a relatively high interest-rate regime within Australia could be important to the fostering of a sustained foreign interest in funding Australian debt issuances. The domestic interest-rate structure works as a signal influencing the stability of expectations about relative exchange rates. Hence one might advance a cautionary note about interest rate easing in the contemporary policy setting when there is much reliance on foreign funding of Australian Government-linked issuances.

\section{An Exit Strategy?}

The minimum period for the maintenance of these guarantees would appear to be to the end of 2011. This horizon allows for the securing of a significant improvement in the stability of economic and financial markets, with some prospects for the restoration of real growth in some major international economies. In light of past experiences during the late nineteen-eighties and early nineteen-nineties, the prospect for a similar achievement in property and real-estate markets would appear less certain.

The Group of Financial Regulators should be soon engaged in reviewing the basis for conveying into the public arena the conviction about the certainty of bank deposits and the other features related to insurers which lay at the centre of the initial work by the group. If this is not done comprehensively and communicated widely then the willingness of the political leadership, government and opposition, to grasp the challenge for abandoning guarantees domestically may be hard to secure. The perpetuation of the ramifications of the guarantees, as witnessed in the funding support for the property aspects of wealth management, brings in its train rewards for those who speculated in asset price inflation. This endorsement would be a remarkable turn of events, illuminating moral hazard. 
The solution to the removal of the government guarantee of issuers in international capital markets lies with the four major banks. The costs of the guarantee arrangements are best seen in terms of the relative benefits accruing to less-well-rated rivals and the addition to costs of funds because of the guarantee fee. Thus any one or all of the four majors might refrain from seeking the guarantee when coming to bring new offerings to markets in coming months. Timing would depend on their appraisal of progress towards the restoration of market liquidity and financial strength of participants.

\section{Closing Comments}

The introduction of measures by the Australian Government to guarantee funds lodged with deposit-taking entities in Australia and guarantee issues of securities by Australian banks in both Australian and international capital markets has brought differentiation between different types of activity in the financial-services sector in Australia. One effect has been to engender support for smaller and less-well-placed financial entities when compared to the four major Australian banks. Another has been to distinguish between deposit-taking entities such as banks, building societies and credit unions, and other activities relying upon drawing funds trusts, managed funds and like activities. Thus there has been market segmentation between the guaranteed and these other entities. This feature was recognised fully by the Australian Government at the time the measures were inaugurated, as was noted earlier in this commentary. This recognition was witnessed in the steps taken by the Australian Government to foster financial support for other types of entity reliant upon managed funds and similar instruments.

With the comprehensive effects of the guarantees as revealed in earlier segments, there is some risk of those entities gaining from the policy measures put in place pursuing activities which would not be possible in other circumstances. In short, there is some prospect of moral hazard applying in these settings. With the issuer guarantee more than the deposit guarantee, there is a basis for expecting the prudential authorities to take steps to ensure that the funding support is not dissipated in fostering riskier asset portfolios. Prudential appraisals would safeguard the strength of the rating associated with the Australian Government's guarantees as well as its own standing in international capital markets at a time when its reliance on these markets to support its official funding requirements is so compelling. 


\section{References}

Australian Office of Financial Management (AOFM) 2009, ‘Purchase of Residential Mortgage-Backed Securities (RMBS) - Announcement of Further Mandates - Second Selection Round Operational Notice 7/2009', 24 March, www.aofm.gov.au

Davis, K. 2004, 'Study of Financial System Guarantees', National Capital Printing, Canberra: xviii and 287.

Gillard, J. 2009, Address to the Australian Reception, World Economic Forum, Davos, Switzerland, 29 January.

HIH Royal Commission 2003, 'A Corporate Collapse and its Lessons', The Failure of HIH Insurance; Vol. 1; April. National Capital Printing, Canberra: lxv and 344.

Reserve Bank of Australia 2006a, Financial Stability Review, 24 March: 68.

Reserve Bank of Australia 2006b, Financial Stability Review, 23 September: 52.

Reserve Bank of Australia 2008, Financial Stability Review, 24 September: 71.

Reserve Bank of Australia 2009, Financial Stability Review, 25 March: 71.

Rudd, K. 2008, 'Global Financial Crisis', media release, 12 October.

Swan, W. 2008, 'Government Announces Details of Deposit and Wholesale Funding Guarantees', media release No. 117, 24 October. 